\title{
AN ANALYSIS OF THE POSSIBILITIES OF APPLICATION OF SERVITIZATION AT SELECTED MANUFACTURING COMPANIES
}

\author{
${ }^{1}$ Vladimira VLCKOVA, ${ }^{2}$ Veronika BALASOVA \\ 1,2 University of Pardubice, Faculty of Chemistry, Pardubice, Czech Republic, EU, \\ vladimira.vlckova@upce.cz,st41945@student.upce.cz
}

https://doi.org/10.37904/metal.2019.985

\begin{abstract}
This paper is dedicated to the problems of servitization and the possibilities of its application in metallurgy. It aims to identify the selected Czech steel manufacturers', steel processors' and casting manufacturers' awareness of the servitization concept and to analyse the possibilities of its application at these companies. On the basis of the conducted professional literature review focussing on the essence of servitization and on the conditions for its application, the websites of the selected companies associated in the Foundry Association of the Czech Republic and the Czech Steel Association were analysed from the point of view of the provided services connected with their products. The conclusion summarizes and evaluates the outcomes of this analysis.
\end{abstract}

Keywords: Servitization, services, steel manufacturers', steel processors', casting manufacturers'

\section{INTRODUCTION}

In view of the given commoditization, it is nowadays very difficult to distinguish yourself in the industrial markets. They are services what creates an added value thanks to which it is possible to differentiate yourself from the competitors. Therefore, servitization is coming to the fore in manufacturing companies. However, the term servitization almost does not exist in the Czech professional literature. The term servitization was first described in the work of [1]. Servitization strategy was first applied in the USA as early as in the 90's of the 20th century, from where it further spread to England and West Europe. It has been developing since then, and nowadays it is an essential part of strategic marketing. [2]. However, the term servitization almost does not exist in the Czech professional literature.

This paper is dedicated therefore to the problems of servitization and the possibilities of its application in metallurgy. It aims to identify the selected Czech steel manufacturers', steel processors' and casting manufacturers' awareness of the servitization concept and to analyse the possibilities of its application at these companies.

The applied research methods and sources include the targeted literature search focused mainly on the essence of servitization and on the conditions for its application and the analyse of the websites of the selected companies. These companies are associated in the Foundry Association of the Czech Republic and the Czech Steel Association from the point of view of the provided services connected with their products.

\section{ESSENCE OF SERVITIZATION}

Servitization is generally described as a process giving products an added value distinguishing them from the competitors [3, 4]. It represents innovative development of an organization, where a company not only offers products, but it can also provide its customers with complex product systems. Primarily, it concerns the B2B market. A company providing a service together with a product often gets more money for the service than for the product itself. Distinguishing through provision of services is thus becoming a characteristic feature of innovative manufacturing companies [5]. 
Servitization can be represented by three steps, characterized by different levels of product range complexity and by integration of various products and services. In the first step, a number of product services aiming to improve its functionality supports product offering and, in the second step, some product services are added to improve processes, and customer services are added to improve relationships with the customer. In the last step, products and services are interconnected to create a new and unique offer in the form of a productservice system [6].

Servitization thus places greater emphasis on the customer's value for the company than on the product technical specification and features. This shift towards services is mostly used when a product reaches its maturity stage, which results in a decrease in the income. And it is the process of adding services to the given product what can turn this decrease. In the event of successful introduction of a product-service system, services can become a source of income and profit, they make sure that the customers are satisfied and support the corporate growth [7].

Park [8] divided different ways of product-service integration into two groups. The first group was proposed before 2000 and it contains different forms of product-service integration focussed on monitoring of marketing targets. It includes Bundling [9], Systems selling [10], Full Service [11], Service package [12], Product service [13], Installed base service [14]. Product-service integration aims to distinguish product offerings.

The second group refers to a change in the strategic orientation of the company. Most of these approaches did not develop until after 2000, and they differ from the above mentioned ones in the fact that products and services are integrated in the primary stage of proposing product ranges in a way to provide functions desired by the customers. Products and services are proposed in a way to be interconnected, but not only added. It includes: Solutions and Integrated solutions [6]), Product-service system (PSS) [15], Functional sales [16], Function product [17], Integrated product and service engineering [6].

\section{CONDITIONS FOR IMPLEMENTATION OF SERVITIZATION}

Within the servitization implementation process, companies can either build up a wide portfolio of conventional services, develop/acquire new services, or offer advanced services closely connected with the product to the degree that they provide customers with an ability rather than with a physical value (e.g. the Pay-per-Kilometre Service provided by the company MAN) [18]. Implementation of servitization in a company may lead to a number of benefits, e.g. an increase in sales, differentiation from competitors, and attracting new customers. However, its implementation is not always necessarily of a benefit for the company. An example can be found in a large multinational company, which at first successfully implemented servitization in the division of compressors, but their later implementation in the division of construction machinery failed. The failure mainly resulted from the high role and functions of the products and unstable customers' operating environment, and from provision of services undervalued by the customers [19].

The transition to servitization process has four steps: consolidation of service-related products; entering the product-related service market; replacement of product-related services by services based on the customercompany relationship and by services concentrated in the processes aiming to increase the customer efficiency; takeover of the final user's operations by the supplier and of the final user's operating risks and processes [14]. The process of servitization itself requires investments, a change in the corporate attitude, significant financial means, and strong confidence. The entire company must be involved. What is a critical aspect is the need for a new set of abilities for development of advanced product lines with a new offering in the market, and often the need for a cultural shift as well. Implementation of servitization thus includes both product range innovation, and innovation of the manufacturing and operating processes. To be successful, Motwani defined six factors: market-oriented service development; identification of customer needs for development of new product-related services, and subsequently services directly supporting the customer; relationship-based marketing; a clearly defined service development process; creation of an independent 
service innovation department; specification of service culture and relating willingness to invest sources into business activities in the area of services [20]. Development of advanced services requires significant changes in the areas of technologies, culture, organizational structure and corporate processes (Baines, 2013). Effective servitization also requires coordination of various entities involved in the supply chain (Pistoni, 2018, str. 41). It is generally believed that increased collaboration among supply chain participants leads to lower total cost and enhanced service performance [21].

\section{FAMILIARITY WITH SERVITIZATION AND POSSIBILITIES OF ITS IMPLEMENTATION IN METALLURGY}

Data pro an analysis of the possibilities of application of servitization and identification of familiarity with it at manufacturing companies were acquired through our own internet questioning and analysis of websites of selected 49 companies associated in the Foundry Association of the Czech Republic and the Czech Steel Association. The companies were sent a questionnaire created and subsequently processed in MS Word and Excel. The questionnaire return rate was, in spite of repeated addressing, $20 \%$ only. The first 5 questions refer directly to servitization, the other then aim to identify the respondents and to describe the company. For their formulation and evaluation, see Tables 1 and 2.

Table 1 Evaluation of the term servitization by manufacturing companies [own study]

\begin{tabular}{|c|l|c|c|c|c|c|c|}
\hline $\begin{array}{c}\text { Number } \\
\text { questions }\end{array}$ & \multicolumn{1}{|c|}{ Question wording } & $\begin{array}{c}\text { Definitely } \\
\text { yes }\end{array}$ & $\begin{array}{c}\text { Yes } \\
\text { Rather } \\
\text { yes }\end{array}$ & $\begin{array}{c}\text { Definitely } \\
\text { No }\end{array}$ & $\begin{array}{c}\text { No } \\
\text { Rather } \\
\text { No }\end{array}$ \\
\hline 1 & Have you come across the term servitization? & 1 & 1 & 1 & 2 & 2 & 3 \\
\hline 2 & Do you understand the term servitization? & 1 & 5 & 1 & 0 & 1 & 2 \\
\hline 3 & $\begin{array}{l}\text { Do you apply servitization strategy at your } \\
\text { company? }\end{array}$ & 1 & 3 & 1 & 3 & 1 \\
\hline 4 & $\begin{array}{l}\text { Do you think it would be convenient to apply } \\
\text { servitization strategy for your product? }\end{array}$ & 2 & 2 & 3 & 2 & 0 & 1 \\
\hline 5 & $\begin{array}{l}\text { Are you considering implementation of } \\
\text { servitization strategy? }\end{array}$ & 2 & 2 & 0 & 4 & 1 \\
\hline
\end{tabular}

Table 2 Questions and answers referring to the respondents [own study]

\begin{tabular}{|c|c|c|}
\hline Number & Question wording & Answers and their relative representation \\
\hline 6 & $\begin{array}{l}\text { How many employees are there at your } \\
\text { company? }\end{array}$ & 50-249 (20\%), více než 250 (80 \%) \\
\hline 7 & What is your position at the company? & $\begin{array}{c}\text { CEO, Sales Director, Marketing Manager, } \\
\text { Innovation Advisor, Technologist (10\%), Assistant } \\
(50 \%)\end{array}$ \\
\hline 8 & $\begin{array}{l}\text { Who is in charge of innovations at your } \\
\text { company? }\end{array}$ & $\begin{array}{l}\text { Research and Development Dept (30\%), Company } \\
\text { Director or Management }(50 \%) \text {, not specified } \\
(20 \%) \text {. }\end{array}$ \\
\hline 9 & $\begin{array}{l}\text { Is your company rather product-oriented or } \\
\text { service-oriented? }\end{array}$ & Product only (50\%), product and services (50 \%) \\
\hline
\end{tabular}

Table 1 show that only a third of the respondents have come across the term servitization. The questionnaire explains the term briefly, and so $70 \%$ of the respondents stated that they understand it, $40 \%$ stated that they are applying this strategy, $70 \%$ of them believe that it would be useful to apply it. $40 \%$ of the respondents plan to implement it at their companies. 
Table 2 implies that answers came mainly from the respondents from companies having 250 and more employees, who constituted $80 \%$. At $50 \%$ of the companies, innovations are dealt with by the Research and Development Departments, and at $30 \%$ of them it is a director or company management. A half of the respondents are product-oriented only, but the second half is also service-oriented.

However, in view of a very low questionnaire return rate, these outcomes cannot be generalized, and so in addition to that, websites of all 49 addressed companies were analysed from the point of view of provided services connected with their products. For the outcomes, see Tables $\mathbf{3}$ and $\mathbf{4}$.

Table 3 The outcomes of the website analysis - relative frequency related to 49 answers [\%] [own study]

\begin{tabular}{|c|c|c|c|c|c|c|c|c|c|c|c|c|c|c|}
\hline \multirow{2}{*}{$\begin{array}{l}\text { Company } \\
\text { size based } \\
\text { on the } \\
\text { number of } \\
\text { employees }\end{array}$} & \multicolumn{2}{|c|}{$\begin{array}{l}\text { Legal form } \\
\text { company }\end{array}$} & \multirow{2}{*}{$\begin{array}{c}\text { Total } \\
\\
\% \\
\end{array}$} & \multicolumn{2}{|c|}{$\begin{array}{c}\text { Czech } \\
\text { firm }\end{array}$} & \multicolumn{2}{|c|}{$\begin{array}{l}\text { Czech } \\
\text { branch }\end{array}$} & \multicolumn{2}{|c|}{$\begin{array}{c}\text { Innovation } \\
\text { dep. }\end{array}$} & \multicolumn{2}{|c|}{$\begin{array}{c}\text { Service } \\
\text { dep. }\end{array}$} & \multicolumn{2}{|c|}{ Services } & \multirow{2}{*}{$\begin{array}{c}\begin{array}{c}\text { Registered } \\
\text { capital }\end{array} \\
{[1000 \mathrm{Kč}]}\end{array}$} \\
\hline & $\begin{array}{l}\text { joint- } \\
\text { stock }\end{array}$ & Ltd. & & Yes & No & Yes & No & Yes & No & Yes & No & Yes & No & \\
\hline small & 2 & 16 & 18 & 16 & 2 & 0 & 18 & 0 & 18 & 14 & 4 & 14 & 4 & $100-112700$ \\
\hline medium & 6 & 33 & 39 & 37 & 2 & 10 & 29 & 6 & 33 & 29 & 10 & 29 & 10 & $100-67100$ \\
\hline large & 35 & 4 & 39 & 33 & 6 & 8 & 31 & 4 & 35 & 27 & 12 & 31 & 8 & $10-12400000$ \\
\hline not specified & 2 & 2 & 4 & 4 & 0 & 0 & 4 & 0 & 4 & 4 & 0 & 4 & 0 & $240-2000$ \\
\hline Total & 45 & 55 & 100 & 90 & 10 & 18 & 82 & 10 & 90 & 73 & 27 & 78 & 22 & $(589,687)$ \\
\hline
\end{tabular}

Table 4 The outcomes of the website analysis - relative frequency related to Company size [\%] [own study]

\begin{tabular}{|c|c|c|c|c|c|c|c|c|c|c|c|c|c|c|}
\hline \multirow{2}{*}{$\begin{array}{c}\text { Company size based } \\
\text { on the number of } \\
\text { employees }\end{array}$} & \multicolumn{2}{|c|}{$\begin{array}{l}\text { Legal form } \\
\text { company }\end{array}$} & \multirow{2}{*}{$\begin{array}{c}\text { Total } \\
\% \\
\end{array}$} & \multicolumn{2}{|c|}{$\begin{array}{l}\text { Czech } \\
\text { firm }\end{array}$} & \multicolumn{2}{|c|}{ Czech branch } & \multicolumn{2}{|c|}{$\begin{array}{c}\text { Innovation } \\
\text { dep. }\end{array}$} & \multicolumn{2}{|c|}{$\begin{array}{c}\text { Service } \\
\text { dep. }\end{array}$} & \multicolumn{2}{|c|}{ Services } & \multirow{2}{*}{$\begin{array}{c}\begin{array}{c}\text { Registered } \\
\text { capital }\end{array} \\
\begin{array}{c}\text { Average } \\
\text { [1000Kč] }\end{array} \\
\end{array}$} \\
\hline & $\begin{array}{l}\text { joint- } \\
\text { stock }\end{array}$ & Ltd. & & Yes & No & Yes & No & Yes & No & Yes & No & Yes & No & \\
\hline small & 11 & 89 & 100 & 89 & 11 & 0 & 100 & 0 & 100 & 78 & 22 & 78 & 22 & 13,436 \\
\hline medium & 16 & 84 & 100 & 95 & 5 & 26 & 74 & 16 & 84 & 74 & 26 & 74 & 26 & 13,407 \\
\hline large & 89 & 11 & 100 & 84 & 16 & 21 & 79 & 11 & 89 & 68 & 32 & 79 & 21 & $1,500,882$ \\
\hline not specified & 1 & 1 & 100 & 1 & 0 & 0 & 1 & 0 & 1 & 1 & 0 & 1 & 0 & 1,120 \\
\hline Total & 45 & 55 & 100 & 90 & 10 & 18 & 82 & 10 & 90 & 73 & 27 & 78 & 22 & $(589,687)$ \\
\hline
\end{tabular}

Table 3 implies that the Foundry association members are mainly large enterprises in the forms of a joint-stock company with the average registered capital of CZK1,500,881,579 and a limited liability company of a medium size from the point of view of the number of employees with the average registered capital of CZK13,407,684, which however comparable with small companies. The majority of them are Czech companies (90\%). Only $10 \%$ of the company websites mention the existence of an innovation department, but $73 \%$ of the companies have an independent service department. Table 4 shows that the existence of a service department and the provided services do not depend on the company size.

The most important area relating to servitization is provided services. Regardless of the company size, the websites of all three groups of companies included the following services: adjustments of delivered models; machining of material/products and their surface finish, as the case may be provided in cooperation; complete product service, services adjusting the product-blasting, hot machining, product pickling and passivation of stainless steel products, sanding and polishing; ingot machining, ingot varnishing, dividing of material into required dimensions, roughing of penetration and pressure tests, ingot attestation under TDP, quality check, measurement and tests, tensile tests, calibration of machined parts, consulting and advisory activity, development and production of a prototype, manufacturing and modification of moulds, 3D model production, 
logistics services, shipping in accordance with the customer's requirements; arrangement of transport, storing, packaging and unspecified services.

In addition to that, medium-sized companies offer: complete services from development and construction of ingots, through production of moulds, selection of the cast iron type, refining, cladding, casting and machining, to the final product in accordance with the customer's requirements; assistance with product development, arrangement of all required tests and attests, dimension check by scanning, 3D ingot measurement, simulation of ingot solidification and filling, complete services in the area of product deliveries, turn-key products; complete solutions for just-in-time deliveries to all countries worldwide, advisory services in the area of metallurgy, repairs of damaged graphite electrodes, refurbishment of slide valve closures of ladles; maintenance, production of special packages in accordance with the customer's requirements.

Large enterprises also offer a welding school; complete services of high quality in the area of sub subcontracting for the automobile industry, a segment of fittings for building and other industries; complete machining, a complete service from product optimization, through production of tools and facilities, casting of semi-finished products, machining, assembly, to handover of a tested product; fork-lift truck rental, ensuring vtools for the period of the product life-cycle, the possibility of laboratory and technical service testing; calculations, mountings, reconstructions, modernization of giant machines and handling technologies; calibration laboratory services, maintenance of technological facilities, material preparation external services, spare parts; permanent product and service development; specialized service, product and repair deliveries in accordance with particular requirements. What is also apposite is the statement of one of the companies: We would do a half of our work if our services ended with development of foundry technologies or production of tools or ingots. To be able to prepare the final product for its final use, it is necessary to conduct a number of additional operations, a lot of which we can ensure directly at our plants, and we buy the others directly from specialists.

\section{CONCLUSION}

Servitization is a process giving products an added value distinguishing them from the competitors It represents innovative development of an organization, where a company not only offers products, but it can also provide its customers with complex product systems. Servitization thus places greater emphasis on the customer's value for the company than on the product technical specification and features Primarily, it concerns the B2B market and is mostly used when a product reaches its maturity stage, which results in a decrease in the income. In the event of successful introduction of a product-service system, services can become a source of income and profit, they make sure that the customers are satisfied and support the corporate growth.

The process of servitization requires investments, a change in the corporate attitude, significant financial means and strong confidence, a new abilities for development of advanced product lines with a new offering in the market, innovation of the product and of the manufacturing and operating processes, market-oriented service development; identification of customer needs for development of new product-related services, relationship-based marketing; a clearly defined service development process; creation of an independent service innovation department; specification of service culture and relating willingness to invest sources into business activities in the area of services, significant changes in the areas of technologies, culture, organizational structure and corporate processes and also coordination of various entities involved in the supply chain.

It is obvious from the above overview of the services that the companies offer a wide portfolio of conventional services relating to the product technical specification and properties, consultancy, quality, repairs, logistics services, etc. However, some of them, mainly medium-sized and large enterprises, offer advanced services closely related to the product in cooperation with other entities of the supply chain. In the future, a number of 
them could provide their customers with an ability, rather than with a physical value. An example can be seen e.g. in lending fork-lift trucks, repairs of damaged graphite electrodes, refurbishment of slide valve closures of ladles; calculations, mountings, reconstructions, modernization of giant machines and handling technologies, permanent product and service development, ensuring tools for the period of the product life-cycle,.

\section{REFERENCES}

[1] VANDERMERWE, Sandra and RADA, Juan. Servitization of business: Adding value by adding services. European Management Journal. 1988. vol. 6, no. 4, pp. 314-324.

[2] ROY, Rajkumar, BAINES, T.S., LIGHTFOOT, H.W., BENEDETTINI, O. and KAY, J.M. 2009. The servitization of manufacturing. Journal of Manufacturing Technology Management. 2009. vol. 20, no. 5, pp. 547-567.

[3] GARCIA, Martin, Carolina, Patricia, SCHROEDER, Andreas and ZIAEE BIGDELI, Ali. The value architecture of servitization: Expanding the research scope. Journal of Business Research. [online]. 2019. [viewed 2019-04-13]. In press, Available from: DOI: 10.1016/j.jbusres.2019.04.010.

[4] LUZ MARTÍN-PEÑA, María and ZIAEE BIGDELI, Al. Servitization: academic research and business practice. Universia Business Review. Portal Universia S .A.. 2016. vol.49, pp. 18-31.

[5] DÍAZ-GARRIDO, Eloísa, PINILLOS, María-José, SORIANO-PINAR, Isabel and GARCÍA-MAGRO, Cristina. Changes in the intellectual basis of servitization research: A dynamic analysis. Journal of Engineering and Technology Management. 2018. vol. 48, pp. 1-14.

[6] PISTONI, Anna and SONGINI, Lucrezia. Servitization strategy and managerial control. 1st. ed. North America: Emerald Publishing. 2017. p.284.

[7] KOWALKOWSKI, Christian, GEBAUER, Heiko and OLIVA, Rogelio. Service growth in product firms: Past, present, and future. Industrial Marketing Management. 2017. vol. 60, pp. 82-88.

[8] PARK, Yongtae, GEUM, Youngjung and LEE, Hakyeon. Toward integration of products and services. Journal of Engineering and Technology Management. 2012. [online]. vol. 29, iss.4, pp.528-545 [viewed 2019-04-07]. Available from: DOI: 10.1016/j.jengtecman.2012.08.002. ISSN 09234748.

[9] GUILTINAN, Joseph P. The Price Bundling of Services: A Normative Framework. Journal of Marketing [online]. 1987.vol. 51, iss. 2, pp. 74-85 [viewed 2019-04-08]. Available from: DOI: 10.2307/1251130.

[10] MATTSSON, Lars-Gunnar, Systems selling as a strategy on industrial markets. Industrial Marketing Management [online]. 1973. Vol.3, iss. 2, pp.107-120 [cit. 2019-04-08]. Available from: DOI: 10.1016/0019-8501(73)90025-4.

[11] STREMERSCH, Stefan, WUYTS, Stefan and FRAMBACH, Ruud T. The Purchasing of Full-Service Contracts. Industrial Marketing Management [online]. 2001. vol. 30, iss.1, pp.1-12 [viewed. 2019-04-08]. Available from: DOI: 10.1016/S0019-8501(99)00090-5. ISSN 00198501.

[12] FITZSIMMONS, James A. and FITZSIMMONS, Mona J. Service management for competitive advantage.1st ed. New York: McGraw-Hill, 1994. p. 462.

[13] FRAMBACH, Ruud T., WELS-LIPS, Inge and GÜNDLACH, Arjan. Proactive product service strategies: An application in the European health market. Industrial Marketing Management [online]. 1997. vol. 26, iss. 4, pp. 341-352 [viewed 2019-04-08]. Available from: DOI: 10.1016/S0019-8501(96)00122-8.

[14] OLIVA, Rogelio and KALLENBERG, Robert. Managing the transition from products to services. International Journal of Service Industry Management [online]. 2003.vol.14, iss. 2, pp.160-172 [viewed 2019-04-08]. Available from: DOI: 10.1108/09564230310474138.

[15] MANZINI, E. and VEZZOLI, C. A strategic design approach to develop sustainable product service systems: examples taken from the 'environmentally friendly innovation' Italian prize. Journal of Cleaner Production [online]. 2003. vol. 11, iss. 8, pp.851-857 [viewed 2019-04-08]. Available from: DOI: 10.1016/S0959-6526(02)00153-1.

[16] AURICH, J. C., FUCHS, C and WAGENKNECHT, C. Life cycle oriented design of technical Product-Service Systems. Journal of Cleaner Production [online]. 2006. vol.14, iss.17, pp.1480-1494 [viewed 2019-04-08]. Available from: DOI: 10.1016/j.jclepro.2006.01.019.

[17] ALONSO-RASGADO, Teresa, THOMPSON, Graham and ELFSTRÖM, Bengt-Olo. The design of functional (total care) products. Journal of Engineering Design [online]. 2004. vol. 5, iss. 6, pp. 515-540 [cit. 2019-04-08]. Available from: DOI: 10.1080/09544820412331271176 
[18] BAINES, Tim and LIGHTFOOT, Howard. Made to serve: how manufacturers can compete through servitization and product service systems. 1st. ed. Chichester, West Sussex, United Kingdom: Wiley. 2013. p. 270.

[19] JOVANOVIC, Marin, ENGWALL, Mats and JERBRANT, Anna. Matching Service Offerings and Product Operations: A Key to Servitization Success. Research-Technology Management [online]. 2016. vol. 59, iss. 3, pp. 29-36 [viewed 2019-04-18]. Available from: DOI: 10.1080/08956308.2016.1161403.

[20] MOTWANI, Jaideep G., GEBAUER, Heiko, FRIEDLI, Thomas and FLEISCH, Elgar. Success factors for achieving high service revenues in manufacturing companies. Benchmarking: An International Journal [online]. 2006. vol.13, iss.3, pp 374-386 [viewed 2019-04-18]. Available from: DOI: 10.1108/14635770610668848.

[21] VLCKOVA, Vladimira. Assessment of cooperation within chosen supply system in the Czech chemical industry. In Business and Management 2016: 9th International Scientific Conference. Vilnius, Lithuania: Vilnius Gediminas Technical University Press, 2016, pp.1-9. Available from: DOI: 10.3846/bm.2016.21. 